\title{
Modelling tourism demand volatility using a seasonal autoregressive integrated moving average autoregressive conditional heteroscedasticity model for Victoria Falls Rainforest arrivals in Zimbabwe
}

\begin{tabular}{|c|c|}
\hline \multicolumn{2}{|c|}{$\begin{array}{l}\text { Authors: } \\
\text { Tendai Makoni }{ }^{1} \text { (1) } \\
\text { Delson Chikobvu }{ }^{1}\end{array}$} \\
\hline \multicolumn{2}{|c|}{$\begin{array}{l}\text { Affiliations: } \\
{ }^{1} \text { Department of } \\
\text { Mathematical Statistics and } \\
\text { Actuarial Science, University } \\
\text { of the Free State, } \\
\text { South Africa }\end{array}$} \\
\hline \multicolumn{2}{|c|}{$\begin{array}{l}\text { Corresponding author: } \\
\text { Tendai Makoni, } \\
\text { tpmakoni@gmail.com }\end{array}$} \\
\hline \multicolumn{2}{|c|}{$\begin{array}{l}\text { Dates: } \\
\text { Received: } 26 \text { Jan. } 2018 \\
\text { Accepted: } 14 \text { Apr. } 2018 \\
\text { Published: } 29 \text { Aug. } 2018\end{array}$} \\
\hline \multicolumn{2}{|c|}{$\begin{array}{l}\text { How to cite this article: } \\
\text { Makoni, T. \& Chikobvu, D., } \\
\text { 2018, 'Modelling tourism } \\
\text { demand volatility using a } \\
\text { seasonal autoregressive } \\
\text { integrated moving average } \\
\text { autoregressive conditional } \\
\text { heteroscedasticity model } \\
\text { for Victoria Falls Rainforest } \\
\text { arrivals in Zimbabwe', Journal } \\
\text { of Economic and Financial } \\
\text { Sciences 11(1), a167. https:// } \\
\text { doi.org/10.4102/jef.v11i1.167 }\end{array}$} \\
\hline \multicolumn{2}{|c|}{$\begin{array}{l}\text { Copyright: } \\
\text { (C) 2018. The Authors. } \\
\text { Licensee: AOSIS. This wc } \\
\text { is licensed under the } \\
\text { Creative Commons } \\
\text { Attribution License. }\end{array}$} \\
\hline \multicolumn{2}{|l|}{ Read online } \\
\hline 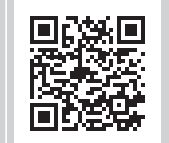 & $\begin{array}{l}\text { Scan this QR } \\
\text { code with your } \\
\text { smart phone or } \\
\text { mobile device } \\
\text { to read online. }\end{array}$ \\
\hline
\end{tabular}

Accurate tourism volatility forecasts for popular tourist destinations, like the Victoria Falls Rainforest, are vital to tourism destination managers and policymakers. The Victoria Falls Rainforest in Zimbabwe is under the town of Victoria Falls and is one of the natural wonders of the world. The rainforest has many exceptional plant species not common in the region and hence attracts many tourists. Financial, political and economic environments differently affect the Zimbabwean tourism industry, as evidenced by large tourist arrival fluctuations. Previous research focused more on tourism determinants than tourism volatilities. Researchers noted political instability and exchange rates as the major Zimbabwean tourism determinants. Estimates of the Victoria Falls Rainforest tourist arrival volatilities are projected using the monthly tourist arrival figures from the Zimbabwe Parks and Wildlife Management Authority and Zimbabwe Tourism Authority. The first difference of logarithmic transformed series is stationary. The univariate $\operatorname{SARIMA}(2,1,0)(2,0,0) 12-\mathrm{ARCH}(1)$ model fits extremely well and provides an informative out-of-sample volatility forecast because it captures tourism volatility effects, dynamics and non-linearity of conditional variances. The results indicate that positive tourism shocks affect tourist arrival volatility positively. Volatility estimates indicated minimal uncertainty in the first half of the forecasted year and then became constant throughout the year. This encourages the continuation of the implementation of new favourable policies and marketing strategies by the government and tourism destination managers to keep the destination distinctive and attractive. The New Zimbabwe political dispensation is likely to enhance investment opportunities at the Victoria Falls Rainforest as a destination because of minimal uncertainties exhibited by volatility forecasts. Potential employment creation, improved economic environment and other positives are some of the expectations from the model results.

\section{Introduction}

Modelling tourism demand volatility is vital for a country like Zimbabwe. Zimbabwe is a developing country in which agriculture and tourism are the largest foreign currency contributors (Dondo, Bhunu \& Rivett 2002). Knowing tourism demand volatility helps the government and tourism managers in policy formulation and decision-making processes, resource smoothing and allocation, and also unearths philosophies and practices that affect tourist arrivals. Modelling tourism volatility gives clear visualisation of the styled arrival behaviour of tourists. Tourism volatility causes uncertainty in future tourist arrivals and results in an unsteady economy, particularly for investors, as tourism investors consider tourism volatility before investing. High tourism volatility is associated with low investment opportunities.

Zimbabwe has many tourist attraction centres, which include the Victoria Falls Rainforest, Great Zimbabwe monuments, Chinhoyi curves and so on. According to the 2015 Zimbabwe National Statistical Agency (ZIMSTAT) report, the Victoria Falls Rainforest is the largest tourist attraction in the country. It is a major contributor to the country and the region's tourism industry. The volume of tourist arrivals at a certain destination depends on the popularity of the destination (Gan 2015). In the Victoria Falls Rainforest, visitors enjoy several activities like bungee jumping, abseiling, a gorge swing, walking with lions, white water rafting, scenic helicopter flights, bush walks, quad and mountain biking, horseback trails as well as fly fishing, among others (ZIMSTAT report 2015). 
The Zimbabwean tourism sector contributes immensely to the country's gross domestic product (GDP), exports, imports and employment (Travel and Tourism Economic Impact, 2015). The Victoria Falls Rainforest tourist destination is the main contributor to the country's GDP (ZIMSTAT report 2015). Christie and Crompton (2001) highlighted that the tourism sector is a major contributor to most African countries' GDP and exports. According to their website (2015), the Southern African Development Community tourism sector contributed US $\$ 940$ billion to the world economy in 2010. The best sector to ease poverty in Africa is the tourism sector (World Bank 2006). According to Interim Poverty Reduction Strategy Paper (2017-2018), tourism is under pillar III of the six pillars of poverty reduction strategies. This shows tourism to be important when it comes to poverty reduction.

Natural disasters, economic and political instability, unfavourable economic policies, increased crime rates and terrorist attacks are some of the factors that cause tourism volatility in developing countries (Lorde \& Moore 2006). In Zimbabwe, currency fluctuations, damaged infrastructure, economic decline, capital flight and political instability between the years 2000 and 2008 resulted in the underperforming of the Zimbabwean tourism industry, including the Victoria Falls Rainforest (Karambakuwa et al. 2011), leading to or coupled with tourism volatility.

The Victoria Falls Rainforest tourism destination managers and policymakers make use of volatility estimates in coming up with flexible and affordable pricing strategies and marketing strategies so as to improve the destination's competitiveness while strengthening the attraction of the destination. Tourism developers and destination managers who are aware of the characteristics of future volatility are in a position to redesign and reposition themselves for survival. They are ready for new tourists from the emerging markets while being aware of the long- and short-term tourism demand fluctuations and effects.

Bhanugopan (2001) pointed out that international tourists will opt for peaceful destinations; the Victoria Falls Rainforest is one of the peaceful destinations in the country, as there are tourism police officers deployed in the town. The Victoria Falls area has never been largely affected by political demonstrations like in other big towns and cities. In studying the impacts of tourism on poverty in South Africa, Saayman, Rossouw and Krugell (2012) concluded that tourism receipts are a poverty alleviation tool in developing countries. However, there are few benefits from tourism income that are channelled to the poor. The availability of accurate tourism volatility forecasts will guide tourism stakeholders and government in resource allocation and smoothing towards the poor. Kester (2003) concluded that poverty, insufficient accommodation and disease are the major blows to tourist arrivals in Africa. There is insufficient accommodation and transport facilities in Victoria Falls, as the town is becoming small compared to the number of tourists. Exchange rates, accommodation and transport prices are some of the influential tourism shocks affecting the Victoria Falls Rainforest and Zimbabwe at large because they influence tourists' decision to visit destinations and the number of days to spend in the destination. To address the mentioned accommodation and transport problems, statistical models will help by providing accurate tourism demand and volatility estimates for the tourism destination town. The estimates will be used for accommodation and transport planning purposes.

Chang and McAleer and Lim (2011) noted that strong domestic currency adversely affects international tourist arrivals. Various different exchange rates by Zimbabwean banks are not favourable to tourists. According to Zunga (2009), tourism players lost confidence in the Zimbabwean currency because of high inflation and this resulted in local currency fluctuations and economic instability. The Zimbabwean currency is weak and the introduction of multiple currencies is favourable to international tourists. Karambakuwa et al. (2011) used a qualitative approach in assessing the initiatives of the Zimbabwe Tourism Authority (ZTA) on tourist arrivals and found that arrivals improved after the introduction of multiple currencies. Political instability, negative media publicity and economic recession influenced tourist arrivals in 2008. The new political dispensation under the new president, Emmerson Mnangagwa, has a positive impact on the tourism industry.

Muchapondwa and Pimhidzai (2011) used an autoregressive distributed lag (ARDL) approach to co-integration in modelling tourism demand for Zimbabwe. The method is good for estimating short- and long-run tourism demand elasticity, but some of its shortfalls are that it is more applicable when there is co-integration among variables. The model does not consider volatility clustering, which is an important aspect in modelling tourism demand and volatility. An adoption of sophisticated methods like the autoregressive conditional heteroscedasticity (ARCH) model, originally designed by Engle (1982), and generalised autoregressive conditional heteroscedasticity (GARCH) model proposed by Bollerslev (1986), provides a detailed analysis on the tourism demand volatilities. A GARCH model is better at capturing volatility clustering and is among several best models (Chand, Kamal \& Ali 2012). It captures tourism volatility effects, dynamics and non-linearity of conditional variances, which the seasonal ARIMA, vector error correction model (VECM), vector autoregressive (VAR) and ARDL fail to capture. VECM, VAR and ARDL models are good at identifying factors that affect tourist arrivals, while seasonal autoregressive integrated moving average (SARIMA) models are good for short-term forecasting with a seasonal component. However, some of these models fail to capture variations in tourism data and they assume equal variances in the tourism series, but most tourism series exhibit unequal conditional variance. A GARCH model can better handle such a process. Amos (2010) noted the importance of GARCH models in dealing with heteroscedasticity as they lead to accurate forecast confidence limits. ARCH and GARCH models take note of all tourism shocks and give a volatility measure that is useful in decisionmaking, policy formulation as well as helping in providing 
information for solving transport and accommodation pricing in the tourist destination town.

Tourism volatility affects employment significantly, the economy (both private and public sectors) and solvency of hotels (Lorde \& Moore 2008; Park \& Jei 2010). There is need for destination-specific statistical tourism volatility models that guide the tourism managers and planners in policy formulation. Unavailability of statistical studies in African tourism leads to poor policy and guidance in the tourism industry (Christie \& Crompton 2001). It is therefore vital for tourism stakeholders, policymakers and the government to have statistical models that are capable of forecasting and explaining tourist arrival volatility.

Every tourist destination has a unique demand and volatility because of several tourism source markets (Hoti, Leon \& McAleer 2004). The purpose of this paper is to model tourism demand and volatility for Victoria Falls Rainforest using a SARIMA-ARCH/GARCH process that accommodates tourism dynamics of conditional variance on the tourist arrivals series. This is the first paper to model Zimbabwe tourism demand volatility using a SARIMA-ARCH/GARCH model and it will contribute to the body of knowledge on the importance of the ARCH/GARCH family of models in the tourism industry. The authors are not aware of any paper that addresses this problem.

\section{Literature review}

The amount of tourism demand research depends on the availability of data according to Song and Li (2008), and this explains why there is more research in America and Europe than in Africa. Rogerson (2007) also emphasised unavailability of enough research in Africa. Xiao and Smith (2006) stated that few tourism demand studies in Africa exist while more studies are available for developed countries. Very few research papers considering tourism demand in Zimbabwe exist in the literature (Karambakuwa et al. 2011; Machipisa 2001; Muchapondwa \& Pimhidzai 2011). Identification of tourism demand factors has been the goal of most research and very few, if any, of these studies have attempted modelling tourism demand and volatility.

Most African studies concentrated on tourism determinants as evidenced by Naudé and Saayman (2004). They used crosssection and panel data in identifying the tourism determinants of 43 African countries and concluded that political instability and infrastructure problems affect most countries. Fourie and Santana-Gallego (2013) also studied determinants of African tourism, while Eita, Jordaan and Jordaan (2011) focused on South African tourism determinants. While using panel data in Ghana, Bentum-Ennin (2014) concluded that the country's image impacts on international tourism demand, whereas Eita and Jordaan (2014) indicated infrastructure as the major tourism determinant in Namibia. Seetanah, Sannassee and Rojid (2015) used the VAR model in analysing the impact of relative prices on Mauritian tourism. They noted that relative price impacts heavily on Mauritian international tourism demand. From all these studies, political stability, marketing, destination development level, tourism infrastructure, price stability and exchange rates are the most influential tourism determinants. The above-mentioned tourism determinants affect tourism demand and volatility in various ways. The SARIMA models are capable of capturing and explaining the effects of tourism determinants (Baldigara \& Mamula 2015) and the models go further to forecasting. This is a missing aspect on most research in Africa. This aspect is critical for decision-making purposes.

In an attempt to come up with useful and accurate future tourism forecasts, Saayman and Saayman (2010) adopted the SARIMA models during modelling South African tourism demand and noted the accuracy of SARIMA models. In Tanzania, Ndiege (2015) used a SARIMA model that produced accurate Tanzanian tourism forecasts. Wan et al. (2013), Lim, Min and McAleer (2008), Chu (2008), Lee, Song and Mjelde (2008), Wang and Lim (2005) and Schulze and Prinz (2009) are some of the scholars who adopted SARIMA models in modelling tourist arrivals and acknowledged their accuracy over other models like the Holt-Winters exponential smoothing model. SARIMA models are used in this study in coming up with a conditional mean equation for tourist arrivals.

Kamel, Ftiti and Chaibi (2015) modelled Tunisian tourism demand using the VECM and noted positive tourism growth because of better exchange rates. GARCH models capture volatility and are applicable to a variety of situations (tourism, finance and electricity). Saayman and Saayman (2013) analysed the relationship between exchange rate volatility and South African tourism using a GARCH model. The model fitted well to the data and shed some light on tourism volatility impacts. Sigauke and Chikobvu (2012) fitted a SARIMA-GARCH model using South African electricity data and the model captured and explained all the electricity volatility characteristics.

Chang, McAleer and Lim (2011) modelled volatility for tourist arrivals from Japan to New Zealand and Taiwan using asymmetric and symmetric volatility models and found mixed results in the two destination countries. In modelling volatility for the Canary Islands, Hoti et al. (2005) found accurate tourism results of conditional volatility from the GARCH $(1,1)$ model after using monthly data. Results showed uncertainty in future tourist arrivals. Chan, Lim and McAleer (2005) noted that conditional variances affect tourism demand when they used three multivariate GARCH models in examining the volatility of Australian tourism demand and various shock effects. The results indicated the importance of knowing future tourism conditional variances to tourism management. Chan et al. (2005) used different GARCH models in modelling tourism demand and volatility for Australia from the UK, USA, Japan and New Zealand. They observed that conditional variances exhibit interdependent effects on all the countries and asymmetric effects because of shocks in two countries. The results were very informative to 
those in the tourism sector because they showed the effects of both negative and positive tourism shocks to the country.

Hoti et al. (2007) fitted multivariate conditional volatility models to the monthly tourism data for Cyprus and Malta as a way of analysing related volatility. Resulting models from the study capture the conditional variance and risk dynamics for Cyprus and Malta. Shareef and McAlear (2005) used GARCH $(1,1)$ and Glosten-Jagannathan-Runkle $(1,1)$ in modelling and forecasting conditional volatility of tourists to Thailand. Results showed that conditional means for the two models varied, while conditional volatility estimates from the models for monthly international tourist arrivals growth rates were sensible. Seo, Park and Yu (2009) proposed the MGARCH model in modelling tourism demand for particular destinations (Thailand, Singapore, the Philippines and Jeju Island) and observed high volatility persistent between the Philippines and Jeju Island as compared to Thailand and Singapore. These results are helpful to the tourism management authorities and government.

Ferenstein and Gasowski (2004) used Autoregressive-GARCH processes in modelling stock returns in Poland after noting unequal variance on the mean equation [an AR(1) model]. De Vita and Kyaw (2013) used a GARCH model to examine exchange rate volatility measures and later found that the exchange rate is a major determinant of tourism demand for the German tourists to Turkey. Tran et al. (2015) used a multiplicative seasonal ARIMA/GARCH model in modelling mobile communication network traffic in Vietnam and found that the $\operatorname{ARIMA}(1,0,1)(0,1,1)_{24}-\operatorname{GARCH}(1,1)$ was a better model for the data. The model produced a good estimation when dealing with volatility clustering and it was a flexible model that captured Easy Virtual Network traffic series well and produced reasonable forecasts. ARCH models explain time-varying conditional variances for tourism and financial data better, according to McAleer and Davino (2008). We propose estimating the models (ARIMA/SARIMA$\mathrm{ARCH} / \mathrm{GARCH}$ ) using Zimbabwe tourism industry data. The data bears similar characteristics.

It has been noted in the literature that tourism demand and volatility can be modelled using causal methods (basic structural method [BSM], VAR model, etc.) and non-causal methods (ARIMA/SARIMA and GARCH models). Noncausal methods are more popular than the causal methods (Saayman \& Botha 2015). Non-causal methods indicate some superiority over causal methods in terms of short-term forecast accuracy (Saayman \& Botha 2015; Saayman \& Saayman 2010; Wan et al. 2013). Various researchers (Lee et al. 2008; Lim et al. 2008) adopted the Box-Jenkins (1976) approach in analysing tourism demand. In this study, the Box-Jenkins methodology is adopted. The SARIMA-ARCH and ARIMA-GARCH models produce accurate volatility forecasts (Brida \& Risso 2011; Coshall 2009); hence they are adopted. The aim of this study is to understand and explain tourism demand volatility and characteristics.

\section{Reviews of methods used}

The monthly tourist arrival series are used in fitting a univariate model; the SARIMA-ARCH/GARCH model in particular.

\section{Stationarity test}

A stationarity test is a prerequisite in most time series modelling; therefore, stationarity of the monthly tourist arrivals series was examined using the augmented DickeyFuller (ADF) test. The ADF test was introduced by Dickey and Fuller in 1979 and the regression model used was

$\Delta Y_{t}=\alpha+\delta T+\beta Y_{t-1}+\sum_{i=1}^{k} \gamma_{i} \Delta Y_{t-i}+\varepsilon_{t}$

where $T$ denotes the deterministic trend, $\Delta Y_{t-i}$ is the lagged first difference to accommodate a serial correlation in the residual term $\varepsilon_{t} \cdot \alpha, \beta, \delta$ and $\gamma_{i}$ are the model parameters to be estimated.

\section{Conditional mean equation}

A conditional mean equation that captures the seasonal characteristics of tourist arrivals was fitted according to the Box and Jenkins (1976) approach and is in the form of a SARIMA model because of its ability to capture seasonality in tourism data. Seasonal autoregressive integrated moving average models can be written as $\operatorname{SARIMA}(\mathrm{p}, \mathrm{d}, \mathrm{q})(\mathrm{P}, \mathrm{D}, \mathrm{Q}) \mathrm{s}$, with $\mathrm{s}$ representing the seasonality period, while $(\mathrm{p}, \mathrm{d}, \mathrm{q})$ and $(\mathrm{P}, \mathrm{D}, \mathrm{Q})$ are the ARIMA and seasonal ARIMA model orders, respectively. $\mathrm{P}$ and $\mathrm{p}$ represent the $\mathrm{AR}$ components, $\mathrm{D}$ and $\mathrm{d}$ represent the level of differencing required to achieve stationarity, while $\mathrm{Q}$ and $\mathrm{q}$ represent the moving average components. The Akaike information criterion (AIC) will be used to select the best mean equation.

\section{Heteroscedasticity and autoregressive conditional heteroscedasticity effect tests}

Tourism series are like financial series: they exhibit unequal variance, and outsized error terms may be expected. This is because of a variety of factors. A time series plot of the meanequation's residual is used tovisualiseheteroscedasticity. The Breusch-Godfrey Lagrange Multiplier test introduced by Engle (1982) is used to test the presence of ARCH effects on the residuals of the conditional mean equation. The test is conducted under the null hypothesis of no ARCH effects on the residuals. The presence of ARCH effects leads to the use of GARCH models.

\section{Autoregressive conditional heteroscedasticity model}

The introduction of $\mathrm{ARCH}$ and GARCH models allowed the modelling of tourism demand volatilities. The ARCH model has two parts, the AR for autoregressive models and the conditional heteroscedasticity derived from the fact that future volatilities influence present information. The future 
tourist arrivals, given the past and present information, can be assumed to be

$T_{t}=\mu_{t}+\sigma_{t} \epsilon_{t}, \epsilon_{t} \sim N(0,1)$.

$T_{t}-\mu_{t}$ is the residuals of arrivals at time $t$ and can be represented as

$a_{t}=\sigma_{t} \epsilon_{t}$

The ARCH(1) model is as follows:

$\sigma_{t}^{2}=\alpha_{0}+\alpha_{1} a_{t-1}^{2}$

where $\alpha_{0}>0$ and $\alpha_{1} \geq 0$ to make the variance positive and $\alpha_{1} \geq 1$ to make it stationary. When dealing with this model, future forecasts' conditional volatility $\sigma_{t+1}^{2}$ will be large if future arrival residuals (many more arrivals than expected or far fewer arrivals than expected) are large in magnitude.

\section{Generalised autoregressive conditional heteroscedasticity model}

The GARCH model is a generalisation of the ARCH. The process has a conditional mean equation and conditional variance equation that need simultaneous estimation because the variance is a function of the mean. The mean equation is as follows:

$T_{t}=\mu_{t}+\epsilon_{t}$

[Eqn 5]

where $\mu_{t}$ represents constant conditional mean and $\epsilon_{t}$ is the residuals, normally distributed. Chang et al. (2009a) pointed out that the GARCH model proposed by Bollerslev (1986) is very useful if the time-varying conditional variance has both autoregressive and moving average components. The proposed $\operatorname{GARCH}(p, q)$ model can be given by the formula:

$\sigma_{t}^{2}=\omega+\beta \sigma_{t-1}^{2}+\alpha e_{t-1}^{2}$

[Eqn 6]

where $\omega>0, \alpha_{i} \geq 0$ and $\beta_{j} \geq 0$ are sufficient conditions ensuring conditional variance, $\sigma_{t}^{2}$ of $y_{t}$ (log-transformed tourist arrival statistics) given available information up to $t-1$ is positive. The first sum corresponds to the GARCH component of order $q$ and the second to ARCH components of order $p$. The GARCH $(1,1)$ model proved to be sufficient in modelling variance; it has been frequently used in many studies and can be presented as follows:

$\sigma_{t}^{2}=\omega+\beta \sigma_{t-1}^{2}+\alpha e_{t-1}^{2}$

[Eqn 7]

where $\alpha$ measures shock persistence in the short run, and $(\alpha+\beta)$ highlights the degree of persistence of volatility in the long run. To ensure that $\sigma_{t}^{2}$ is positive, $\omega, \alpha$ and $\beta$ must also be positive; that is $(\alpha \geq 0$ and $\beta \geq 0)$. The sum of $\alpha$ and $\beta$ must be strictly less than 1 to ensure the stationarity condition $(\alpha+\beta<1)$. The results of the estimated $\operatorname{GARCH}(\mathrm{p}, \mathrm{q})$ model can be used to forecast future conditional variance through the formula:

$\sigma_{t+k}^{2}=\omega+\sum_{j=1}^{q} \beta_{j} \sigma_{t+k-j \mid t}^{2}+\sum_{i=1}^{p} \alpha_{i} e_{t+k-i \mid t}^{2}$

[Eqn 8]

\section{Persistence volatility}

The persistence of tourism volatility implies that the current conditional variance would never decrease. The presence of persistence increases future investment uncertainty, especially in the tourism sector and the financial sector. It is measured by the half-life of the decay coefficient; $(\alpha+\beta)$ determines the rate at which the variance forecast converges to the unconditional variance (long-run or short-run volatility persistence).

\section{Results}

The data were analysed using the $\mathrm{R}$ and Minitab software packages. The Zimbabwe Parks and Wildlife Management Authority (ZPWMA) and the ZTA provided the 12-year period (January 2006 through December 2017) monthly tourism data for modelling purposes. The Victoria Falls Rainforest is jointly managed by the ZPWMA and ZTA. Both the ZPWMA and ZTA were involved in the data collection and are the custodians of the tourism data.

\section{The model}

An ADF test on the original series $X_{t}$ showed the series to be non-stationary at the 5\% significance level (Dickey-Fuller = $-8.6454, p=0.07)$. The data were stationary after a first difference of the logarithm-transformed series (DickeyFuller $=-7.7752, p=0.01$ ). The autocorrelation function (ACF) and partial autocorrelation function (PACF) suggested a $\operatorname{SARIMA}(2,1,0)(2,0,0)_{12}$ model as the primary model. The data fit the model. Various competing models and their AIC values are summarised in Table 1.

Both the graphs in Figure 1, the sequence plot of standardised residuals and ACF of the residuals, looked satisfactory, though there is one significant spike in the ACF. The fitted model captures the dependence of tourist arrivals series well.

\section{Volatility clustering and autoregressive conditional heteroscedasticity effect}

The squared residuals of the $\operatorname{SARIMA}(2,1,0)(2,0,0)_{12}$ model were used to verify the presence of volatility clustering and this helped in determining the modelling process of the innovations.

There is evidence of volatility clustering in Figure 2, because small fluctuations bunch together and bigger fluctuations bunch together on both the return series (grey line) and residual series (blue line). There are numerous periods with

TABLE 1: Seasonal autoregressive integrated moving average model results.

\begin{tabular}{ll}
\hline SARIMA model & AIC \\
\hline SARIMA $(2,1,0)(1,0,0)_{12}$ & -18.16 \\
$\operatorname{SARIMA}(1,1,0)(1,0,1)_{12}$ & -22.17 \\
$\operatorname{SARIMA}(0,1,1)(0,0,1)_{12}$ & -10.92 \\
$\operatorname{SARIMA}(1,1,0)(1,0,0)_{12}$ & -2.74 \\
SARIMA $(2,1,0)(2,0,0)_{12}$ & -28.35 \\
\hline AIC, Akaike information criterion; SARIMA, seasonal autoregressive integrated moving average.
\end{tabular}

The SARIMA $(2,1,0)(2,0,0)_{12}$ model is the best model according to AIC, as shown in Table 1. 


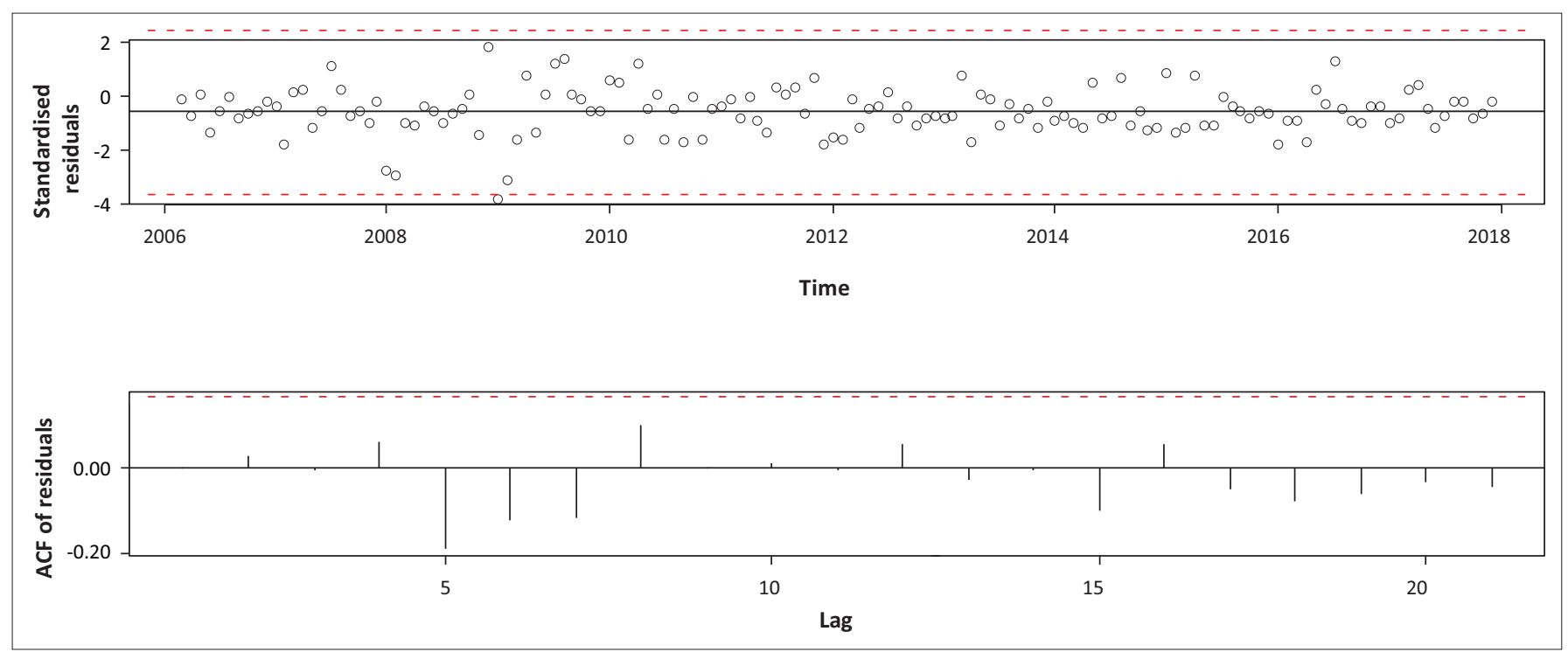

ACF, autocorrelation function; SARIMA, seasonal autoregressive integrated moving average.

FIGURE 1: Diagnostic display for the SARIMA $(2,1,0)(2,0,0)_{12}$ model.

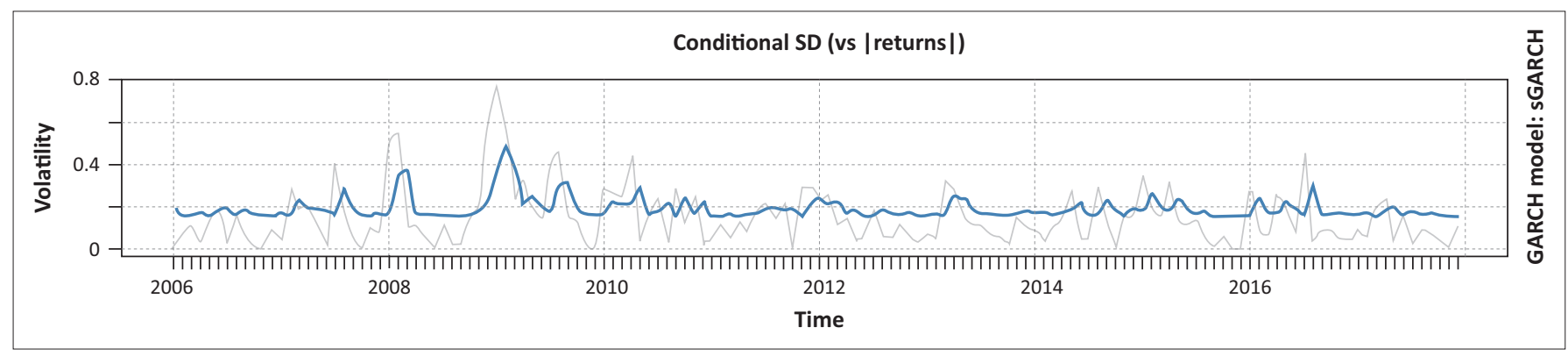

SD, standard deviation.

FIGURE 2: Volatility clustering results.

high volatility between 2008 and 2010 as well as around the end of the study period, possibly because of the presidential elections held in Zimbabwe between March 2008 and June 2008, the formation of the Government of National Unity in February 2009 and the adoption of a multi-currency system in August 2009. Volatility clustering and the presence of the ARCH effect on model residuals was done using an $\mathrm{ARCH}$ test. The test results (chi-squared $=72.25$ and $p=0.00261$ ) were highly significant, suggesting the rejection of the null hypothesis of no ARCH effect at the 5\% significance level, implying that model residuals are time varying. The results allow modelling of the innovations using a GARCH process.

\section{Generalised autoregressive conditional heteroscedasticity model estimation}

Several GARCH models under different error distribution assumptions (normal, Student's $t$ and generalised error distribution [GED]) were fitted and the best model was selected according to their AIC and Bayesian information criterion (BIC).

According to both AIC and BIC, the ARCH(1) model under normal distribution assumption captures the $\mathrm{ARCH}$ effect well, as suggested by the results in Table 2. The ARCH(1)
TABLE 2: Estimated generalised autoregressive conditional heteroscedasticity models with Akaike information criterion and Bayesian information criterion values.

\begin{tabular}{lcc}
\hline Model & $\begin{array}{c}\text { Akaike information } \\
\text { criterion }\end{array}$ & $\begin{array}{c}\text { Bayesian information } \\
\text { criterion }\end{array}$ \\
\hline ARCH(1)-norm & -0.48 & -0.42 \\
GARCH(1,1)-norm & -0.46 & -0.38 \\
GARCH(1,1)-std & -0.47 & -0.37 \\
GARCH(1,1)-ged & -0.47 & -0.37 \\
ARCH(1)-std & -0.48 & -0.40 \\
\hline
\end{tabular}

$\mathrm{ARCH}$, autoregressive conditional heteroscedasticity; GARCH, generalised autoregressive conditional heteroscedasticity.

TABLE 3: Autoregressive conditional heteroscedasticity(1) (ARCH[1]) model parameters.

\begin{tabular}{lcccc}
\hline Coefficients & Estimate & Standard error & $t$ & $\operatorname{Pr}(>|\mathrm{t}|)$ \\
\hline$\omega$ & 0.025182 & 0.003990 & 6.31142 & 0.000000 \\
$\alpha_{1}$ & 0.350092 & 0.350092 & 2.67303 & 0.007517 \\
\hline
\end{tabular}

model parameters, estimated using the maximum likelihood estimator, are displayed in Table 3.

All the model coefficients in Table 3 are statistically significant at $1 \%$ and their signs are appropriate. These results are similar to those of Chang, McAleer and Slottje (2009b) and Chang et al. (2010) in their Taiwan and Malaysian studies, respectively, who found lower and positive ARCH coefficients. The positive $\mathrm{ARCH}$ effect implies that positive tourism shocks-like 
improved economic stability-improved exchange rate, zero cases of outbreaks of deadly diseases and improved security services in the destination town increase tourist arrivals variation in the Victoria Falls Rainforest. Negative shocks, like high crime rate, affect tourism growth negatively. A low ARCH coefficient of 0.350092 indicates the steadiness of short-term tourism volatility effects on tourist arrivals and economic status of the destination. Tourism products and services (transport, accommodation, etc.) in the tourist destination will not be greatly affected; hence investors can freely invest in the destination's tourism activities because of low or reduced volatility (a measure of risk).

\section{Residual analysis for autoregressive conditional heteroscedasticity(1) model}

The standardised residuals plot is done through an ACF plot to check serial correlation on the $\mathrm{ARCH}(1)$ residuals.

It is reasonable to confirm the nonexistence of a residual pattern besides the existence of one significant spike observed in Figure 3. Checking for normality of standardised residuals is done by using $\mathrm{Q}-\mathrm{Q}$, probability density plots and the Jarque-Bera test.

Figure 4 supports the acceptance of the null hypothesis of normality on residuals because both groups are approximating a normal distribution. Furthermore, the $p$-value of 0.0362 of the Jarque-Bera test suggests the acceptance of normality at $5 \%$ significance level. All diagnostic results suggested that the ARCH(1) model was the correct model; therefore it can be used to forecast future volatility.

Tourism volatility forecasting is important in the tourism industry because it gives a picture of future uncertainty in

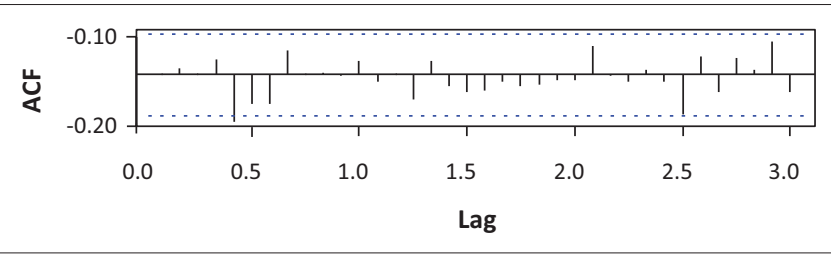

FIGURE 3: Autocorrelation function (ACF) of autoregressive conditional heteroscedasticity(1) process' standardised residuals. tourism arrivals, as this guides revenue contribution policies. The root mean square error (RMSE) of the $\mathrm{ARCH}(1)$ was very low (0.2561) compared to other fitted models. It is used to forecast future volatility for the next 12 months (January 2018 - December 2018).

The forecasted volatility values in Table 4 suggest that $\hat{\sigma}$ will significantly vary positively with time in the first 6 months of 2018, indicating uncertainties in future tourist arrivals at the Victoria Falls Rainforest. This uncertainty may affect the revenue generated from this tourist destination. The second half of 2018 indicates constant volatility.

There is minimal profound volatility clustering being exhibited by the $\mathrm{ARCH}(1)$ model, thereby resembling results obtained by Hoti et al. (2004) and those from financial data. These volatility estimates play a pivotal role in effectively managing the Victoria Falls Rainforest tourism growth and volatility, for the benefit of the country and community. Based on the model results, there is less risk (because of the constant volatility forecasts of the last 6 months) associated with the increased tourism demand in the destination town, which is good for tourism investors. Furthermore, it would be a noble idea for tourism stakeholders to collaborate with the Victoria Falls Rainforest community so that they can come up with new tourism products and services that will benefit everyone, including the poor. Volatility persistence in tourism is evidenced by the $\mathrm{ARCH}(1)$ model because it provides a reasonable ground for considering policy amendments, such as reducing duty on all tourism-related items (equipment) and removing visas for all neighbouring countries. The responsible tourism authorities and tourism destination managers should amend tourism policies to suit the projected uncertainties, as this will lure both domestic and international tourists, resulting in improved foreign currency reserves.

TABLE 4: Future Victoria Falls Rainforest volatility estimates.

\begin{tabular}{lccc}
\hline Time & Sigma $(\hat{\boldsymbol{\sigma}})$ & Time & Sigma $(\hat{\boldsymbol{\sigma}})$ \\
\hline$t+1$ & 0.1674 & $t+7$ & 0.1968 \\
$t+2$ & 0.1871 & $t+8$ & 0.1968 \\
$t+3$ & 0.1935 & $t+9$ & 0.1968 \\
$t+4$ & 0.1957 & $t+10$ & 0.1968 \\
$t+5$ & 0.1964 & $t+11$ & 0.1968 \\
$t+6$ & 0.1967 & $t+12$ & 0.1968 \\
\hline
\end{tabular}

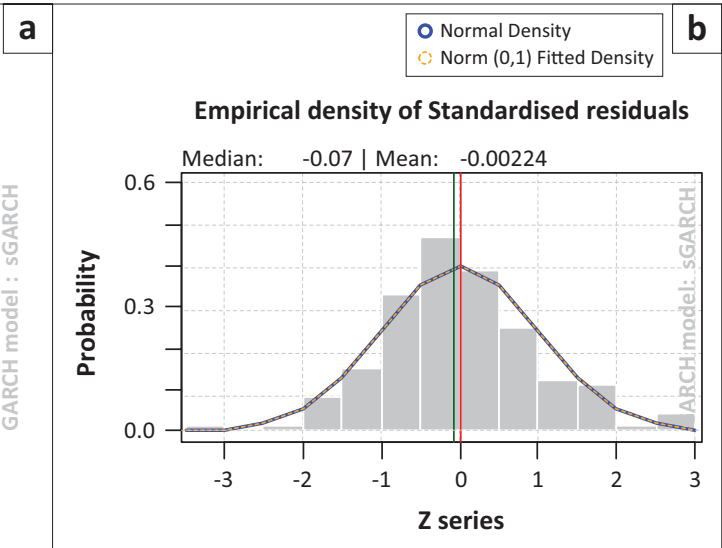

FIGURE 4: Q-Q plot and probability density plot of the autoregressive conditional heteroscedasticity(1) process' standardised residuals. 


\section{Conclusion}

The paper modelled the Victoria Falls Rainforest volatility using monthly aggregated tourist arrivals from January 2006 to December 2017. The empirical results suggested that the first difference of the log transformation of the monthly tourist arrival series is stationary. A SARIMA $(2,1,0)(2,0,0)_{12}$ model was found to be the best mean equation according to the AIC and BIC. The innovations showed volatility clustering and the presence of $\mathrm{ARCH}$ effects. An $\mathrm{ARCH}(1)$ process fits well with the innovations under the normal distribution assumption. The fitted model captured volatility persistence observed between the years 2008 and 2009. The Jarque-Bera tests, RMSE, ACF plot, Q-Q plot and probability density plot of the residuals confirmed the statistical adequacy of the model. The volatility estimates for 2018 produced by the $\mathrm{ARCH}(1)$ indicated steadiness of short-term shocks to tourism volatility, although an increase in the first half of 2018 is observed, followed by a stationary period through the end of 2018. Tourism destination managers must amend some of the existing unfavourable policies and continue implementing new favourable policies and marketing designs in the tourism industry and country so that the destination remains distinctive and attractive. The minimal uncertainty exhibited by the volatility forecasts is likely to give rise to increased and safer investment opportunities in the destination town. Furthermore, the potential employment creation environment in the country and destination town may result from reduced uncertainty.

\section{Acknowledgements}

The authors would like to acknowledge the ZPWMA and the ZTA which assisted with the data for the research.

\section{Competing interests}

The authors declare that they have no financial or personal relationships that may have inappropriately influenced them in writing this manuscript.

\section{Authors' contributions}

T.M. analysed the data and wrote the article. D.C. provided the initial ideas and proofread the article.

\section{References}

Amos, C., 2010, 'Time series modeling with application to South African inflation data', A thesis submitted to University of Kwazulu Natal for the degree of Masters of Science in Statistics.

Baldigara, T. \& Mamula, M., 2015, 'Modelling international tourism demand using seasonal ARIMA models', Tourism and Hospitality Management 21(1), 19-31.

Bentum-Ennin, I., 2014, 'Modelling international tourism demand in Ghana', Global Business and Economics Research Journal 3, 1-22.

Bhanugopan, R., 2001, 'Tourism development in Papua New Guinea: Strategies for success', Asia Pacific Journal of Tourism Research 6(2), 65-73.

Bollerslev, T., 1986, 'Generalized autoregressive conditional heteroskedacity', Journal of Econometrics 31, 307-327. https://doi.org/10.1016/0304-4076(86)90063-1

Box, G.E.P. \& Jenkins, G.M., 1976, Time series analysis: Forecasting and control, Holden-Day, San Francisco, CA.

Brida, J.G. \& Risso, W.A., 2011, 'Research note: Tourism demand forecasting with SARIMA models the case of South Tyrol', Tourism Economics 17, 209-221. https:// doi.org/10.5367/te.2011.0030
Chan, F., Lim, C. \& McAleer, M., 2005, 'Modelling multivariate international tourism demand and volatility', Tourism Management 26, 459-471. https://doi.org/ 10.1016/j.tourman.2004.02.013

Chand, S., Kamal, S. \& Ali, I., 2012, 'Modeling and volatility analysis of share prices using ARCH and GARCH models', World Applied Sciences Journal 19,77-82.

Chang, C., McAleer, M. \& Lim C., 2011, 'Modelling the volatility in short and long haul Japanese tourist arrivals to New Zealand and Taiwan', International Journal of Tourism Science 12, 1-24.

Chang, C.L., McAleer, M., and Tansuchat, R., 2011. Crude oil hedging strategies using dynamic multivariate GARCH, Energy Economics, 33(5), 912-923.

Chang, C., Thanhanok, K. \& McAller, M., 2009a, 'A panel threshold model of tourism specialization and economic development', International Journal of Intelligent Technologies and Applied Statistics 3, 159-86.

Chang, C.-L., McAleer, M. \& Slottje, D.J., 2009b, 'Modelling international tourist arrivals and volatility: An application to Taiwan', in B.H. Baltagi, E. Sadka (series eds.) \& D. Slottje (vol. ed.), Contributions to economic analysis: Vol. 288, Quantifying D. Slottje (vol. ed.), Contributions to economic analysis: Vol. 288, Quantifying
consumer preferences, chap. 11, pp. 299-315, Emerald Group Publishing, Bingley.

Chang, C.L., Khamkaew, T., McAleer, M. \& Tansuchat, R., 2010, Interdependence of international tourism demand and volatility in leading ASEAN destinations, Working Paper No.27/2010 [Online], viewed 17 October 2017, from http://www. econ.canterbury.ac.nz/RePEc/cbt/econwp/1027.pdf

Christie, I. \& Crompton, D., 2001, Tourism in Africa, Working Paper Series No 12, World Bank Africa Region, Washington, DC.

Chu, F., 2008a, 'A fractionally integrated autoregressive moving average approach to forecasting tourism demand', Tourism Management 29, 79-88. https://doi. org/10.1016/j.tourman.2007.04.003

Coshall, J.T., 2009, 'Combining volatility and smoothing forecasts of $\{$ UK $\}$ demand for international tourism', Tourism Management 30, 495-511. https://doi.org/ 10.1016/j.tourman.2008.10.010

De Vita, G. \& Kyaw, K.S., 2013, 'Role of the exchange rate in tourism demand', Annals of Tourism Research 43, 624-627. https://doi.org/10.1016/j.annals.2013.07.011

Dondo, C.H., Bhunu, S.T. \& Rivett, U., 2002, 'GIS in tourism - A Zimbabwe perspective', The International Archives of the Pholoprammetry, Remote Sensing and Spatia Information Science 34(6), 197-200.

Eita, J.H. \& Jordaan, A.C., 2014, 'Estimating the tourism potential in Namibia' Corporate Ownership and Control Journal 11, 391-398. https://doi.org/10.22495/ cocv11i4c4p2

Eita, J.H., Jordaan, A.C. \& Jordaan, Y., 2011, 'An econometric analysis of the determinants impacting on businesses in the tourism industry', African Journal of Business Management 5, 666-675.

Engle, R., 1982, 'Autoregressive conditional heteroscedasticity with estimates of the variance of United Kingdom Inflation', Econometrica 50, 987-1007. https://doi. org $/ 10.2307 / 1912773$

Ferenstein, E. \& Gasowski, M., 2004, 'Modelling Stock Returns with AR-GARCH Processes', SORT 28, 55-68.

Fourie, J. \& Santana-Gallego, M., 2013, 'The determinants of African tourism' Development Southern Africa, Taylor and Francis Journals 30(3), 347-366.

Gan, Y., 2015, An empirical analysis of the influence of exchange rate and prices on tourism demand. Project submitted as partial requirement for the conferral of M.Sc.in Business Administration. Travel and Tourism Economic Impact. [Online], viewed 10 September 2017, from https://www.wttc.org/-/media/files/re

Hoti, S., León, C.J. \& McAleer, M., 2004, 'International tourism demand and volatility models for the Canary Islands', International Congress on Environmental Modelling and Software 113, 1-7.

Hoti, S., McAleer, M. and Shareef, R., 2005,' Modelling country risk and uncertainty in small island tourism economies', Tourism Economics 11, 159-183.

Hoti, S., McAleer, M. and Shareef, R., 2007, 'Modelling international tourism and country risk spillovers for Cyprus and Malta', Tourism Management 28, 1472-1484.

Kamel, J., Ftiti, Z. \& Chaibi, H., 2015, 'The Tunisian Tourism Business: What we learn about the European Demand?', The Journal of Applied Business Research 31 2079-2090. https://doi.org/10.19030/jabr.v31i6.9476

Karambakuwa, R.T., Shonhiwa, T., Murombo, L., Mauchi, F.N., Gopo, N.R., Denhere, W. et al., 2011, 'The impact of Zimbabwe tourism Authority initiatives on tourist arrivals in Zimbabwe (2008-2009)', Journal of Sustainable Development in Africa $13,68-77$.

Kester, J.G.C., 2003, 'International tourism in Africa', Tourism Economics 9, 203-221. https://doi.org/10.5367/000000003101298367

Lee, C., Song, H. \& Mjelde, J., 2008, 'The forecasting of international Expo tourism using quantitative and qualitative techniques', Tourism Management 29, 10841098. https://doi.org/10.1016/j.tourman.2008.02.007

Lim, C., Min, J. \& McAleer, M., 2008, 'Modelling income effects on long and short haul international travel from Japan', Tourism Management 29, 1099-1109. https:// doi.org/10.1016/j.tourman.2008.02.012

Lorde, T. \& Moore, W.R., 2008, 'Modeling and forecasting the volatility of long-stay tourist arrivals', Tourism Analysis 13, 43-51. https://doi.org/10.3727/108354208784548742

Machipisa, L., 2001, Sun sets on Zimbabwe tourism, viewed 21 September 2017, from http://news.bbc.co.uk/1/hi/world/africa/12202218.stm

McAleer, M. \& Davino, J.A., 2008, 'Modelling the growth and volatility in daily international mass tourism to Peru', unpublished paper, Department of Economics, Catholic University of Brasilia, Brazil.

Muchapondwa, E. \& Pimhidzai, O., 2011, 'Modelling international tourism demand for Zimbabwe', International Journal of Business and Social Science 2, 71-81. 
Naude, W.A. \& Saayman. A., 2004, 'The Determinants of Tourism Arrivals in Africa: A Panel Data Regression Analysis', A paper Prepared for the International Conference, Centre for the Study of African Economics, St. Catherine's College, University of Oxford, March 2004, 21-22.

Ndiege, B. O., 2015, 'An Analysis of the Performance of International Tourism Demand in Tanzania', ARA: Journal of Tourism Research 5(1), 53-62.

Park, S.Y. \& Sang Jei, Y., 2010, 'Determinants of volatility on international tourism demand for South Korea: An empirical note', Applied Economics Letters 17(3) 217-223.

Rogerson, C.M., 2007, 'Reviewing Africa in the global tourism economy', Development Southern Africa 24, 361-379. https://doi.org/10.1080/03768350701445350

Saayman, A. \& Botha, I., 2015. 'Evaluating non-linear approaches in forecasting tourist arrivals', Economic Research Southern Africa. Tourism Economics 23(3), 594-613

Saayman, A. \& Saayman, M., 2010, 'Forecasting tourist arrivals in South Africa', Acto Commercii 10, 281-293. https://doi.org/10.4102/ac.v10i1.141

Saayman, A. \& Saayman, M., 2013, 'Exchange rate volatility and tourism-revisiting the nature of the relationship', European Journal of Tourism Research 6, 104-121.

Saayman, M., Rossouw, R. \& Krugell, W., 2012, 'The impact of tourism on poverty in South Africa', Development Southern Africa 29, 462-487. https://doi.org/10.1080/ 0376835X.2012.706041

Schulze, P.M. \& Prinz, A., 2009, 'Forecasting container transshipment in Germany', Applied Economics 41, 2809-2815. https://doi.org/10.1080/000368408022 60932

Seetanah, B., Sannassee, R., \& Rojid, S., 2015, 'The impact of relative prices on tourism demand for Mauritius: An empirical analysis', Development Southern Africa 32(3) 363-376.

Seo, J.S., Park, S.Y. \& Yu, L., 2009, 'The analysis of the relationships of Korean outbound tourism demand: Jeju Island and three international destinations', Tourism Management 30, 530-543. https://doi.org/10.1016/j.tourman.2008.10.013
Shareef, R. \& McAlear, M., 2005, 'Modelling international tourism demand and volatility in Small Island Tourism Economics', International Journal of Tourism Research 7(6), 313-333.

Sigauke and Chikobvu, 2012, 'Short-term peak electricity demand in South Africa', African Journal of Business Management 6(32), 9243-9249.

Song, H. \& Li, G., 2008, 'Tourism demand modeling and forecasting: A review of recent research', Tourism Management 29, 203-220. https://doi.org/10.1016/j.tourman. 2007.07.016

Tran, Q.T., Ma, Z.H., Li, H.C., Hao, L. \& Trinh, Q.K., 2015, 'A multiplicative seasona ARIMA/GARCH model in EVN Traffic Prediction', International Journal Communications, Network and System Sciences 8, 43-49. https://doi.org/10.4236/ ijcns.2015.84005

Travel and Tourism Economic Impact, 2015, Travel and Tourism Economic Impact. [Online], viewed 10 August 2017, from https://www.wttc.org/-/media/files/ reports/economic-impact-research/countries-2017/zimbabwe2017.pdf

Wan, S.K., Wang, S.H., and Woo, C.K., 2013. 'Aggregate vs. disaggregate forecast: Case of Hong Kong', Annals of Tourism Research 42 (0), 434-438.

Wang, Y. \& Lim, C., 2005, 'Using time series models to forecast tourist flows', Proceedings of the 2005 International Conference of Simulation and Modelling, 24-26 October 2005.

World Bank, 2006, Ethiopia: Towards a strategy for pro-poor tourism, Africa Private Sector Development Note 24, World Bank, Washington, DC.

Xiao, H. \& Smith, S., 2006, 'Case studies in tourism research: A state of-the-art analysis', Tourism Management 27, 738-749. https://doi.org/10.1016/j.tourman.2005.11.002

Zimbabwe National Statistics Agency (ZIMSTAT) Reports, 2012-2015, Quarterly digest of statistics (2012-2015), Government of Zimbabwe, Harare, Zimbabwe.

Zimbabwe Tourism Authority (ZTA) Report, 2011, Annual Report, Government of Zimbabwe.

Zunga, N., 2009, 'Zimbabwe Hospitality sector-Undeniable long term value given the country prime tourism assets', IMARA Investing 2009, 1-2. 